\title{
The Lochaber Water Power Scheme
}

\begin{abstract}
$\mathrm{A}^{\mathrm{N}}$
$\mathrm{N}$ article on "The Lochaber Hydro-Electric Power Undertaking", in NATURE of November $29,1930(126,848-849)$, described the first and main portion of an engineering scheme of considerable magnitude by which water from a catchment area of 303 square miles in Inverness-shire is being collected and led to a power station at Fort William, near the foot of Ben Nevis, which will have an ultimate capacity of 120,000 horse-power-by far the largest installation of its kind in Great Britain. The first instalment of the undertaking, costing about three million sterling, utilized the natural reservoir in Loch Treig by means of a tunnel pipe line to Fort William, and was completed in 1930. The second in the sequence of three stages of development was commenced shortly thereafter and completed in 1934, at a cost of another million. It forms the subject of a paper read on December 15 before the Institution of Civil Engineers by Mr. A. H. Naylor, who was chief assistant engineer to Mr. B. N. Peach, the resident engineer for the undertaking under Messrs. C. S. Meik and Halcrow of Westminster, the consulting engineers responsible for the design and supervision of the works from their inception. The following information of interest is extracted from Mr. Naylor's paper. Reference should be made to the map of the district which appeared in the issue of NATURE mentioned above.

The second stage comprises essentially the col. lection of the discharges from the Loch Laggan and Loch Ossian catchment areas into a reservoir formed by the construction of a dam at the western end of the former and the diversion of the impounded water through a tunnel to Loch Treig, with the provision of further storage through the construction of a dam at the northern end of Loch Treig. Loch Treig is the
\end{abstract}

main storage reservoir of the system, and the construction of the dam raises the overflow level from the original height of $+784 \mathrm{ft}$. O.D. to $+819 \mathrm{ft}$. O.D., a capacity of 7,838 million cub. ft. being obtained above the lowest level ( $+695 \mathrm{ft}$. O.D.) to which it can be drawn down. By arranging that the Loch Laggan reservoir should be capable of being drawn down to $+804 \mathrm{ft}$. O.D. and should spill at $+820 \mathrm{ft}$. o.D., a further storage capacity of 1,480 million cub. $\mathrm{ft}$. is rendered available. The tunnel connecting the two lochs, constructed almost entirely through rock of good quality, has a fall of $15 \mathrm{ft}$. in its length of $2 \frac{3}{4}$ miles. The cross sectional outline is made up of circular segments, giving a width inside the concrete lining of $14 \frac{1}{2} \mathrm{ft}$. and a height of $13 \frac{1}{2} \mathrm{ft}$. Three streams passing over the tunnel are diverted into shafts leading into the tunnel.

The Laggan dam is noteworthy as representing the first instance in Great Britain of the embodiment of a large siphon spillway in the design. Six siphon units are installed having shaft diameters of $4 \mathrm{ft} .6 \mathrm{in}$., fitted with jet dispersers at their outer extremities, the intakes being $3 \mathrm{ft}$. high by $6 \mathrm{ft}$. 10 in. wide. By inclining the outlets at $30^{\circ}$ above the horizontal, it is calculated that the issuing jet will strike the river bed at about a maximum distance from the toe of the dam and reduce to a minimum the danger to the dam from vibration or undermining.

For the third and final stage of development it is contemplated to divert the waters of the upper Spey westward into the River Pattack which flows into Loch Laggan, so that, whereas originally the River Spean flowed into the River Spey to discharge into the North Sea, under the projected scheme, the Spey will flow into the Spean and discharge into the Atlantic Ocean.
BRYSSON CUNNINGHAM.

\section{Forestry Research in the Malay Peninsula}

$\mathrm{T}$ HE annual report for 1935 of the Forest Research Institute of the Malay Forest Department has been recently issued, as also the Programme of Research for 1936 (Kuala Lumpur : Forest Department, 1936). Owing to financial difficulties, these reports are reproduced from typescript.

The Institute has been under Mr. J. G. Watson and Mr. E. J. Strugnell during the year. The cost of maintenance is a charge on the budget of the Forest Department, and this in recent years of financial depression has necessitated considerable economies. It is said that the funds available for apparatus and travelling have been limited, and it has been impossible to provide technical subordinates, to whom a great deal of the routine which has fallen on the shoulders of the senior staff could have been entrusted.

The curtailment of research work has been taking place in many parts of the British Empire; but it is a short-sighted policy where existing unworked and only partially known tropical and subtropical forests are concerned, which represent a part of the capital assets of the country containing them. It is this want of recognition that the large forest tracts in so many of the Dependencies and Colonies of the British Empire represent an undeveloped capital of considerable potential value upon which funds must be put out if it is to be developed (as in the case of the primary development of a gold or other mines) which is delaying progress; whilst in many cases the forest capital is deteriorating in value under the eurrent and injurious practices of the users.

The report deals with the work of the rarious branches of the Institute--sylviculture, botany, wood technology, timber mechanics, seasoning and wood working, timber preservation and durability, and the investigations carried out in the chemical and entomological branches. A brief description of the education work carried out at the Forest School is appended to the report.

The work described for the year indicates the wide field which is now being covered by the research 
officers, and a careful study of the report proves that research work of the very highest value, not only to the Department concerned but also to the country as a whole, is being carried out.

The programme of research for 1936 indicates the lines of work to be undertaken under the different branches; but in some cases it is noted that suggested work must be postponed until there is an officer avail. able to undertake it.

In the Malayan Forest Records, No. 12 (Malay States Govt. Caxton Press, Ltd,, Kuala Lumpur, 1936), Mr. H. E. Desch, wood technologist, discusses "Commercial Timbers of the Malay Peninsula. No. 1, The Genus Shorea", botanical notes being contributed by the forest botanist, Mr. C. F. Symington. Mr. Desch had started a series of articles on Malayan timbers in the Malayan Forester but gave them up in order to concentrate on the production of this record, as a new method of treatment had become necessary.

"Further investigation disclosed," says the author, "that the then-accepted groups, in the case of timbers of the genus Shorea particularly, were arbitrary and unworkable. For example, having described the timber of nemesu (S. pauciflora), it was found that the description fitted timbers of the meranti tembaga (S. leprosula) type in most essential respects, while the timbers of species allotted, at that time, to the meranti bakau group were not really dissimilar. It was apparent that the attempt to set up divisions in a group of timbers so similar to one another was impracticable, while the assumption that differences did exist was responsible for some of the prevailing misconceptions and might well lead to further inaccuracies." Mr. Desch therefore decided to classify the timbers of a genus on their anatomical structure, general appearance and physical properties, irrespective of existing conceptions of classification. The first genus to be so treated was Shorea, the most important source of timber in the Peninsula, and it has been found that the classification of species conformed elosely with Mr. C. F. Symington's parallel botanical studies.

Concentrating on the more salient features of groups of species, 47 species have been dealt with in six more or less natural divisions, but repetition has not been entirely eliminated. This overlapping was felt to be unavoidable until features of specific significance are better understood.

The treatment of his subject is both useful and instructive and although, as $\mathrm{Mr}$. Desch says, the publication is a compromise in an endeavour to cater for those interested in the scientific study of wood, and those engaged in the practical utilization of timber, it is none the less interesting for that reason.

\section{Education in England and Wales*}

\begin{abstract}
$\mathrm{T}$ $\mathrm{HE}$ report of the Board of Education for the year 1935, published under the title "Education in 1935", is, in the main, like those of previous years. The volume is, as usual, a compendium of facts and figures duly arranged in successive chapters, dealing all too briefly with subjects which range from the elementary school to adult education, as well as the museums at South Kensington and Bethnal Green which are financed out of the Board's vote, and the whole miscellany is supplemented by tables of statisties, of which it may safely be said that they are more detailed and elaborate than those which are supplied by the Ministry of Education of any other European country. It is, in fact, not so much an account of 'Education in 1935' as a bare record, with little by way of comment or suggestion to relieve it, of the Board's administration during the year in question.
\end{abstract}

In one respect, the report makes a welcome new departure. The year of King George V jubilee has provided an occasion in an opening chapter for an interesting survey of education since the King's accession in 1910, a period which has witnessed "a more conscious recognition of the claims of the individual and a greater emphasis on the development of each child according to his bent and capacity". Though there is no room for complacency, it will scarcely be denied that there has been marked progress over the whole field. The abolition of halftime attendance at elementary schools, and of exemptions before fourteen years of age, has resulted in an increase of 87 per cent in the number of children over thirteen in these schools; out of 20,854 schools,

* Education in 1935, being the Report of the Board of Education and the Statistics of Public Education for England and Wales. (London: His Majesty's Stationery Office, 1936.) 38. 6d. net.
4,760 are new or have been extensively enlarged; the education given in the schools is less bookish and more practical, the percentage of schools for children over 11 which make provision for handicraft having risen from 23 in 1910 to 65 to-day: lastly, the re-organization of the elementary system with its provision for "advanced instruction", as adumbrated in the Hadow Report, though long overdue and still incomplete, has at least gone so far that 55 per cent of the older children are in reorganized schools.

The developments in technical education include the establishment of grouped courses and of the scheme of examinations for National Certificates. The provision in the Act of 1918 for a system of parttime day continuation classes for adolescents of 14-18 years is discreetly referred to as "a plan which would ... have had a profound influence on the system of Technical Education and the relations of the schools with industry and commerce". This is an understatement. It would, we think, be true to say that this provision of the 1918 Act, had it been implemented, would have had social and educational results not less important than those which have followed from the Act of 1902 ; and the failure of successive Governments to tackle the problem of adolescent education is one of the most lamentable omissions of post-War statesmanship.

As for secondary education, the years from 1910 to 1935 cover nearly the whole period during which secondary schools have existed as an integral part of the State system of education. The growth in the number, size and efficiency of these schools, in which the elementary school teacher of to-day will usually have been educated and from which the technical schools and colleges now derive a large proportion of their students, may justly be regarded 